\title{
An Evaluation of Extensive Reading Course Book -Contemporary College English: Companion Reader ${ }^{*}$
}

\author{
SU Yan-fei \\ Sichuan University of Arts and Science, Dazhou, China
}

\begin{abstract}
With China's Reform and Opening-up deepening and globalization developing rapidly, global exchanges of variety are growing in frequency in China, resulting in an urgent demand for a large number of people who can speak English. Therefore, the cause of English language teaching enjoys vigorous development in China. Usually, the English language teaching attaches emphasis to English listening, speaking, reading, writing, and translating. Reading is one of the integral parts, deserving great attention, so does the reading course book, whose quality and suitability exert a huge impact on reading teaching. Consequently, based on relevant principles proposed by Day and Bamford (2002), Renandya (2007), and Maley (2009), this paper aims to evaluate a course book, Contemporary College English: Companion Reader, hoping it could bring certain insight into reading course book evaluation under the guidance of relevant reading principles.
\end{abstract}

Keywords: course book, evaluation, extensive reading, extensive reading teaching

\section{Introduction}

With the global ESL/EFL teaching booming, the research in this field enjoys rich diversity. It is no doubt that extensive reading plays a crucial role in second/foreign language acquisition. Studies conducted by a large number of scholars have already demonstrated the value of extensive reading (Mason \& Krashen, 1997; Macalister, 2008; Nuttall, 1982; Renandya, 2007). Renandya (2007) pointed out, "the benefits derived from diverse studies on extensive reading in many different contexts are so compelling that it will be inconceivable for teachers not to make it an important feature of their reading" (p. 133). Nowadays, teachers are increasingly realizing the importance of extensive reading so that an independent extensive reading course has been established in colleges and universities in China. Some extensive reading courses gain a success, while others have less satisfied results. There are numerous factors which influence the success of operating the course of intensive reading, one of which is the reading course book, whose quality and suitability exert influence on reading teaching. How does a teacher or a researcher evaluate the quality and suitability of an extensive reading course book and are there relevant principles for extensive reading and reading teaching guiding the evaluation? This paper aims to deal with the two questions by evaluating an extensive reading course book under the guidance of relevant principles.

\footnotetext{
* Acknowledgements: This paper is supported by Sichuan University of Arts and Science (Grant No.: 2015GJ016Y). SU Yan-fei, lecturer, M.A., School of Foreign Languages, Sichuan University of Arts and Science.
} 


\section{The Teaching Context}

The course book of extensive reading which is evaluated is the second edition of Contemporary College English: Companion Reader, which was published by Foreign Language Teaching and Research Press in 2010, a major publisher in China. Some colleges and universities adopt it as their course book. The teaching context is restricted to the university in which the author works. The adoption of this course book appreciates a history of at least five years at the university. Nowadays, there are about 300 students who major in English using the course book. These students are sophomores. Without any accompanying materials such as teacher's manual, $\mathrm{CD}$, or online materials, the course book is used for only one semester, about 17 teaching weeks, 1.5 hours per week.

The course book is composed of two parts, 41 units and key to exercises in each unit. The teacher usually chooses about 14 units to teach in class and the remaining parts are left to students to read outside classroom without any compulsory requirements for students to read or do assignments. Each unit mainly consists of title, author's name, illustration, passage, glosses (some words or sentences with their Chinese translations), about the author, and exercises (open-ended questions for comprehension and discussion). There is no preface or instruction for course book use attached. As for the theories and principles of the course book, the editors did not give any explanation. Nonetheless, it might be self-evident that this is an extensive reading course book because it is rarely to see a course book which has 41 units for just one semester. This is likely to put one of extensive reading theories into practice, that is, a large amount of input (Krashen, 2009; Nuttall, 1982; Renandya, 2007).

\section{Evaluation}

Scholars conducted studies about intensive reading and extensive reading, which demonstrate that extensive reading is of great importance to improve English proficiency such as vocabulary, writing, reading speed, listening, and speaking. Nuttall (1982, p. 168) pointed out, "The best way to improve one's knowledge of a foreign language is to go and live among its speakers. The next best way is to read extensively in it" (as cited in Renandya, 2007, p. 136). Krashen (2009) believed "only one method of improving reading ability really works: engaging in a great deal of interesting (better yet, compelling), comprehensible reading" (p. 20). Two points should be emphasized: "a great deal" and "comprehensible".

Based on the top 10 principles for teaching foreign language reading, Day and Bamford (2002) put forward proposal for teaching extensive reading as follows:

(1) The reading material is easy;

(2) A variety of reading material on a wide range of topics must be available;

(3) Learners choose what they want to read;

(4) Learners read as much as possible;

(5) The purpose of reading is usually related to pleasure, information, and general understanding;

(6) Reading is its own reward;

(7) Reading speed is usually faster rather than slower;

(8) Reading is individual and silent;

(9) Teachers orient and guide their students;

(10) The teacher is a role model of a reader. 
As for characteristics of extensive reading, the following points are summarized by Renandya (2007, pp. 144-145):

(1) Students read large amounts of material;

(2) Students usually choose what they want to read;

(3) Reading materials vary in terms of topic and genre;

(4) The material students read is within their level of comprehension;

(5) Students usually take part in post-reading activities;

(6) Teachers read with their students, thus modeling enthusiasm for reading;

(7) Teachers and students keep track of student progress.

Maley (2009) presented a digest of principles for successful extensive reading as follows:

(1) Students read a lot and read often;

(2) There is a wide variety of text types and topics to choose from;

(3) The texts are not just interesting: They are engaging/compelling;

(4) Students choose what to read;

(5) Reading purposes focus on: pleasure, information, and general understanding;

(6) Reading is its own reward;

(7) There are no tests, no exercises, no questions, and no dictionaries;

(8) Materials are within the language competence of the students;

(9) Reading is individual, and silent;

(10) Speed is faster, not deliberate and slow;

(11) The teacher explains the goals and procedures clearly, then monitors and guides the students;

(12) The teacher is a role model.... a reader, who participates along with the students.

The above-mentioned principles for extensive reading and reading teaching could be used as criteria for evaluating extensive reading course book. Taking the above-mentioned scholars' viewpoints into consideration, this paper evaluates the course book mainly from the following perspectives:

(1) Is the amount of reading materials abundant?

(2) Are there various interesting topics or text types?

(3) Does the material fulfill the purpose of reading: pleasure, information, and general understanding?

(4) Do students have a faster speed while reading?

(5) Is the material within students' language competence?

First of all, the course book could be evaluated as "good" in light of the amount of material. There are 41 units for one semester. Furthermore, passages are long, varying from about 6 to 55 pages. And the illustrations might be utilized by teachers to do brain-storming work, to attract students' attention and trigger their interests. Therefore, students could read as much as possible.

Secondly, in terms of the variety of reading material, the course book does not necessarily satisfy this criterion. On the one hand, all passages are literary works, mainly story-telling instead of authentic texts which revolve around present lives. It is possibly that students would not be interested in the monotonous text types. On the other hand, there are 3 authors who were born in 1800s-1850s, 9 in 1860s-1890s, 25 in 1900s-1950s, and none was born in 1960s to present (see Figure 1). It is therefore not difficult to figure out that a majority of passages were probably published before 1950s. Since they have been published for such a long time, students are very likely not to enjoy reading them because students who use this course book nowadays are born in the 
21 th century. Under the background of rapid development of science and technology, Internet technology and media, which exert a great influence on present students, most Chinese students love Chinese, Japanese, and South Korean soap operas, American TV series, numerous types of films, entertainment gossips, science fiction, romantic fiction, and the like, such kind of passages as teaching material in classroom might have difficulty in attracting students' attention and triggering their interests. Of course, it does not mean that such type of passages is not good, but maybe it is much better to be used as readers outside classroom. Moreover, topics are largely not related to student's real world so that they might not be interested because given the fierce competition job market, most students are more eager to read things which could be directly beneficial for them to find a good job.

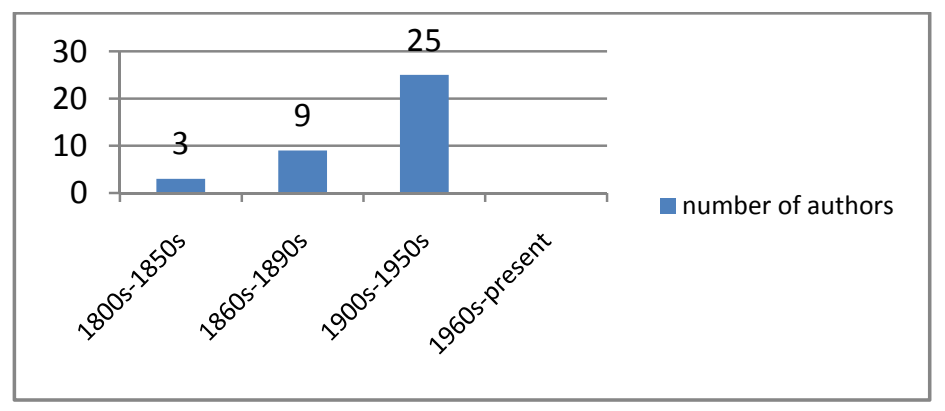

Figure 1. Number of authors.

Thirdly, it is very possibly that the material could not stimulate students to gain pleasure, information, and general understanding while reading them because the material is too difficult for students to read. How to judge the difficulty of material could be proceeded from two aspects: comments from teachers and students and the "five finger rule". To begin with, according to the interview with the course teachers, most of them gave a $7-8$ scale in terms of the difficulty of this course book (1-10 scale). First, some pointed out that when they read the passages while making class planning, they confronted new words which hindered their understanding and consulted dictionaries frequently, which disrupted their thinking and reading. Second, students complained that they could not understand the passages because there were so many new words that they felt much depressed while reading and did not want to read them anymore. Another aspect is the "five finger rule" and the website of Macmillan Dictionary which uses symbol of star to annotate word frequency. Although the "five finger rule" is often used to choose a right book for children, it might be true of choosing the right extensive reading book for college students. As for the "five finger rule", you first open to a page of the book and begin reading; then, you hold up one finger each time when you come to a word you do not know; finally, after you finish reading the page, you check how many fingers you are holding up (0-1 fingers as easy, 2-3 fingers as just right, 4-5 fingers as too hard). Two passages in the course book were taken as an example. Eight words on the first page of the first passage might be new words to students because their frequency were consulted respectively on the website of Macmillan Dictionary (reverie with 0 star, fanatic 0 star, pound 3 stars but has nothing to do with the meaning in the passage, remembrance 0 star, trudge 0 star, haunt 1 star, last 3 stars but also has nothing to do with the meaning in the passage and dire 0 star). Six words on the first page of the second passage were checked (stripe with 1 star, shriek 0 star, indicate 3 stars, lethal 0 star, terminate 0 star, apprehensive 0 star). Obviously, it could be said that difficulty of the material reaches the degree of frustration for students. Therefore, students would not read with pleasure and gain general understanding. 
Fourthly, since difficulty of material reaches the degree of frustration, it is very possibly that students would consult dictionaries or tools frequently while reading, which hinders their reading and understanding. Furthermore, passages are mainly literary works and out-of-date topics which are not related to students' real world lives, so students could not avail themselves of their prior knowledge to understand the passage. Therefore, it could be imaginable that students are unlikely to have a natural faster reading speed.

Last but not the least, the material is well beyond students' competence because there are numerous new words with less frequency, topics are obsolete and unauthentic, and text type is monotonous. Besides, the exercises are dull and difficult, which are open-ended questions, leaving an impression that exercises are too difficult because most Chinese students are accustomed to objective exercises such as multiple choices and cloze. Although the open-ended questions are comprehensive, covering both basics and thought-provoking meaning of the passage, 41 passages have a total of 587 open-ended questions, which would place great psychological burden, pressure, and anxiety on students.

\section{Suggestions}

According to the above-mentioned evaluation of the course book, it is hard to believe it having the suitability of being extensive reading course book, though it has a high quality of material. Consequently, suggestions are proposed as follows:

Firstly, the course book itself is a good book with a great deal of input, while the problem lies in that it is not comprehensible input, beyond the language proficiency of sophomores, so it is advisable that it be adopted by seniors or as outside classroom readers; otherwise, certain passages should be replaced with easier ones within students' competence. Moreover, the sequence of passages could be arranged from the easier to the advanced or the shorter to the longer.

Secondly, it would be better if there is a preface or teacher's manual which introduces the course book and guides teachers to utilize it effectively. Besides, some relevant recommendations for further readers would be better.

Thirdly, text types should be of variety and advance with times so that students would be more interested in them and read extensively and pleasantly. Authentic material could be added. Siegel (2014) suggested that teachers had better choose "topics that are realistic and practical for L2 English users into language classrooms to better prepare students for the "world out there"' (p. 363).

Finally, it would be more acceptable to reduce the amount of open-ended exercises and diversify exercises. Interesting word exercises could be included such as crossword puzzles, filling blanks and relevant word games, comprehension exercises with multiple choices or cloze.

\section{Conclusion}

Under the guidance of extensive reading and extensive reading teaching principles (Day \& Bamford, 2002; Krashen, 2009; Maley, 2009; Nuttall, 1982; Renandya, 2007), this paper evaluates the course book of extensive reading for sophomores majoring in English, mainly from perspectives of amount, variety, difficulty of reading material and purpose and speed of reading. The results show that the course book has abundant input for students to read extensively; however, the abundant input is not all comprehensible input because most passages have a number of new words to students and are beyond their language proficiency, which frustrates them, and text types are comparatively homogenous and monotonous, which students find dull and unreadable; 
furthermore, topics out of date are not closely related to real world. Consequently, the course book, if it would be used as extensive reading course book for sophomores, perhaps needs certain kinds of changes such as to replace certain passages with easier ones, to arrange passages from the easier to the advanced, to use various text types, reduce and diversify exercises, and the like.

\section{References}

Day, R., \& Bamford, J. (2002). Top ten principles for teaching extensive reading. Reading in a Foreign Language, 14(2). Retrieved from http://nflrc.hawaii.edu/rfl/October2002/day/day.html

Krashen, S. (2009). Anything but reading. Knowledge Quest, 37(5), 18-25.

Macalister, J. (2008). Implementing extensive reading in an EAP programme. ELT Journal, 62(3), 248-256.

Maley, A. (2009). Extensive reading: Why it is good for our students...and for us. Retrieved from http://www.teachingenglish.org.uk/article/extensive-reading-why-it-good-our-students\%E2\%80\%A6-us

Mason, B., \& Krashen, S. (1997). Extensive reading in English as a foreign language. System, 25(1), 91-102.

Nuttall, C. (1982). Teaching reading skills in a foreign language. London: Heinemann Educational.

Renandya, W. A. (2007). The power of extensive reading. Regional Language Centre Journal, 38(2), 133-149.

Siegel, A. (2014). What should we talk about? The authenticity of textbook topics. ELT Journal, 68(4), 363-375.

YANG, L. M., CHEN, Y. P., HOU, Y. L., GONG, Y., \& LI, Y. W. (Eds.). (2010). 现代大学英语: 阅读 (Contemporary college English: Companion reader). Beijing: Foreign Language Teaching and Research Press. 